Article

\title{
An Insight into the Commercial Viability of Green Roofs in Australia
}

\author{
Nicole Tassicker, Payam Rahnamayiezekavat * and Monty Sutrisna \\ School of Built Environment, Curtin University, Bentley WA 6102, Australia; \\ nicole.tassicker@graduate.curtin.edu.au (N.T.); monty.sutrisna@curtin.edu.au (M.S.) \\ * Correspondence: p.zekavat@curtin.edu.au; Tel.: +61-089-266-7136
}

Academic Editors: Vivian W. Y. Tam, Khoa N. Le and Liyin Shen

Received: 12 April 2016; Accepted: 21 June 2016; Published: 28 June 2016

\begin{abstract}
Construction industries around the world have, in recent history, become increasingly concerned with the sustainability of building practices. Inherently, the development of the built environment results in partial or complete destruction of the natural environment. Advanced European and North American countries have turned to green roofs as a means of sustainable development. Australia, on the other hand, has yet to fully realize the potential of green roof technology. In the first case, an extensive review of green roof literature was undertaken to establish the dominant perspectives and over-riding themes within the established body of international literature. The collection of primary data took the form of qualitative, semi-structured interviews with a range of construction practitioners and green roof experts; landscape architects, consultants and academics. The information gained from the interviews facilitated the primary aim of the paper; to critically analyse the state-of-practice in the Australian green roof industry. Green roofs, despite their proven sustainability benefits and their international success, have experienced a relatively sluggish uptake in the Australian construction industry. With this being said, the Australian green roof industry is considered to have promising potential for the future; should there be legislative changes made in its favour or greater education within the industry. To advance the local industry, it was found that government authorities are required to adapt policy settings to better encourage the use of green roofs, whilst industry bodies are required to host better, more targeted educational programs.
\end{abstract}

Keywords: sustainability; green roof; commercial viability; Australia

\section{Introduction}

The construction of the built environment inherently involves some, if not total degradation of the natural environment [1]. The processes of construction, operation and ultimate demolition of man-made structures irrevocably alters the natural ecosystem [2]. In response, the global construction industry has developed an on-going commitment to rectify unsustainable trends in development [3]. As a result of this continuing moral conscience, great interest has been shown in sustainable construction practices; particularly elements of green design.

One specific aspect of green design, green roofs, has been touted as a tool for climate change mitigation given the apparent sustainability benefits, socially, economically and environmentally [4]. The numerous and wide ranging benefits of green roof technology have been widely recorded in the international body of knowledge. The fact that green roofs are extensively used in Europe and North America and even mandated in France is a testament to their efficiency as a sustainable roofing system. With this in mind, the question is begged: why is the use of green roof technology not more prevalent in Australia?

A green roof can be defined as an engineered roofing system that features multiple functional layers, including, but not limited to, a waterproofing membrane, a drainage system, a substrate layer 
and, finally, a vegetated surface [5-7]. Green roofs can be one of two recognized types: "extensive" or "intensive" [8]. The categorization of green roofs into either an extensive or intensive classification is determined on the depth of the supportive and vegetative layers.

The green roof industry is very much in its infancy in the Australian construction industry [9]. The difficulties that have previously hindered the uptake of Australian green roofs are widely considered to be a lack of standards, high installation costs, climatic concerns and a lack of reliable research [10]. It is noted within the current body of knowledge that a lack of national research is one of the most recognizable barriers to wider implementation of Australian green roofs [11,12]. The current state of the Australian green roof industry is underpinned by the need for greater domestic research and the ensuing development of local knowledge.

The aim of this paper is to report a recent study on general perceptions of green roof technology within the Australian construction industry with the view to promote the local green roof industry in the years to come. The specific objectives of the paper are as follows:

(1) To bring together expert views on how to advance the local industry and the realistic likelihood of doing so.

(2) To determine the critical factors affecting the commercial viability of green roof implementation; and how these factors currently impact on the local industry.

(3) To determine the most effective ways to promote green roof promotion within the construction industry at the moment.

\section{Green Roof as a Sustainable Technology}

The views of Kucukvar and Omer (2013) [13] regarding the inherent conflict between the natural and built environments are shared by Carter and Laurie (2008) [14], who determine that natural ecosystems are irrevocably altered through the process of development. Kibert [15] agrees that there is an obvious need for construction technologies and development processes to become more sustainable.

In considering a universal definition of "sustainable development", the Brundtland report [16] noted the concept to be "development that meets the needs of the present without compromising the ability of future generations to meet their own needs". A number of key literature pieces recognize that green roofs represent a solution, either fully or in part, to the requirement of the construction industry to become more sustainable. Bianchini and Hewage [17] and Fietosa and Wilkinson [18] all agree that green roofs outperform conventional roofing in specific sustainability realms-social, economic and environmental aspects; the triple bottom line of sustainability $[19,20]$.

It is widely recognized throughout the literature that green roofs offer a vast array of sustainability benefits, such as reduced stormwater runoff, mitigation of noise, favourable lifecycle costing and significant amenity and aesthetic value [21,22]. The individual benefits of green roofs, however, can all be broadly categorized into the three aspects of sustainability: social, economic and environmental.

Throughout the international body of literature, economic and environmental aspects of sustainability are widely researched at the expense of the social sustainability dimension [23]. After recognizing the lack of research, Claus and Sandra (2012) [24] converted social aspects of sustainability into quantifiable measures by undertaking a cost benefit analysis to determine the personal and social aspects within green roofs. They found that "the inclusion of social costs and benefits improves their value".

Interestingly, Gatersleben and White (2010) [25] undertook a unique qualitative study whereby they assessed the validity of people's perceptions and opinions on the aesthetic value of green roofs. They noted that people's generalizations may impact on their perception of green roofs, whilst [26] determined that some people consider green roofs "visually inappropriate".

In direct contrast to these outlying views, the predominant opinion is that people generally perceive vegetation to be more favourable than traditional built forms [27-29]. Hietanen et al. [30] and Farrell et al. [31] evidenced that aspects of green design within a building will induce a more positive experience for users. 
The economic benefits of green roofs are widely documented in the international body of knowledge. Bruce et al. [32] express that despite the well-documented environmental benefits of green roofs, the relatively-high initial cost of construction presents as a significant concern for building owners and developers alike. Forbes [33] specifically labelled the construction cost of green roofs as "indefensibly high", whilst evidencing the statistic [34] that construction costs of traditional roofs range between $\$ 7$ and $\$ 15 /$ square foot compared to a rate of $\$ 15-\$ 70 /$ square foot for green roof systems. It was widely found from comparative lifecycle studies that despite higher initial construction costs, green roofs economically outperform traditional roofing options over their lifecycles $[35,36]$. It is widely noted that a reduction in the maintenance costs of green roofs is the main contributory factor to favourable lifecycle costings [37,38].

The environmental benefits of green roofs are as equally recognized as the economic benefits of green roofs within the international body of knowledge. Forbes [30] recognized that despite the limitation of green roofs to single-handedly 'solve' global environmental concerns, they are a "multifunctional approach to ameliorating many different environmental problems". The findings of $[39,40]$ suggest that effective stormwater management is the greatest environmental benefit offered by green roof systems. McIntyre and Snodgrass [41] reaffirm this dominant view, explicitly noting that stormwater management is "the green roof benefit that has been most aptly documented and validated by research".

The local body of knowledge regarding green roof implementation in Australian climatic conditions is limited [42]. Beecham et al. [43] established that significant disparity exists between the green roof body of knowledge in Australia and that of the advanced European and North American knowledge base. James and Metternich [44], however, note that despite the apparent lack of local data, there is enough information to determine that the contribution from green roofs is positive, and thus, they are worthy of promotion. Elliot [45] indicates that green roof technology has the greatest potential in the hot-dry climatic conditions that typify Australia.

\section{Methodology}

Semi-structured interviews were selected as the most appropriate method of collecting primary data. The structure of the interviews was not rigid in the sequencing or wording of the questions; rather, the interviewees' responses would guide the direction of the conversation and its findings. The interviews aimed to subjectively evaluate people's perception of green roofs

Bearman and Michalski [46] specify that semi-structured interviews are particularly useful where there is little previously known about the subject matter. Given the infancy of the green roof industry in Australia, the selection of semi-structured interviews to elicit qualitative, attitudinal data was deemed most appropriate for the study. Assessment of the themes is undertaken through measuring the perceptions and opinions of those who are closely involved with the subject matter [47].

A purposive collection of academics, practicing consultants and landscape architects was recruited as the target sample. The sample consisted of nine individuals, each with a practical or theoretical knowledge of green roofs in Australia.

An indicative number of questions was sent to each of the interviewees prior to the arranged meeting to ensure that the candidates had the opportunity to familiarize themselves with the intended content. It was made clear to each interviewee that the indicative agenda of questions was flexible and able to be adapted in any way to suit their experiences. The interview questions, as provided in Appendix A, were categorized into 4 main sections, which were specifically designed to closely relate to each of the study's objectives.

The interview participants were selected from a range of backgrounds (i.e., landscape architects, academics and consultants) with varying levels of experience in the construction industry and with green roofs. The profiles of the interviewees are included in Appendix B. 


\section{Results}

Figure 1 depicts the outcomes from the interview. It suggests that the key factors that affect the commercial viability of green roofs include the cost implications of constructing green roofs, education/awareness among practitioners, as well as the role of government bodies in facilitating its adoption, for example through the setting of national policies or the development of incentive schemes. The three main actors identified to have a critical role to play in the promotion of green roofs are private clients, government bodies and industry bodies. However, some concerns were raised about the current effectiveness of industry bodies. Detailed findings from the interview are further discussed in this section based on the three objectives highlighted.

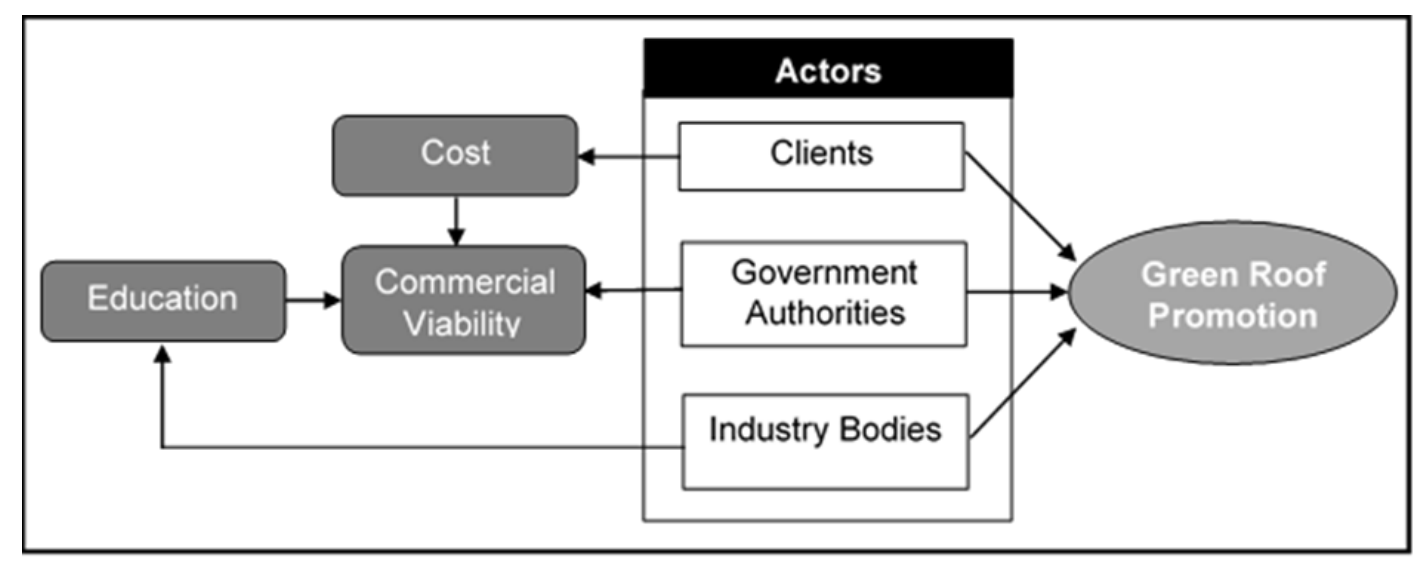

Figure 1. Network of interactions among key factors affecting the promotion of green roof.

\subsection{Collective View Regarding the State of the Local Industry}

The holistic construction industry and its sub-industries, such as architecture, project management and sub-contracting, are generally aware of green roof technology and its potential in the Australian marketplace. A general observation from the interviews was that the construction sub-industries were typically hyper-aware of the potential for negative outcomes to occur in green roof projects; such as roof leakages and cost blowouts.

\subsubsection{Industry Perception}

When asked how positively or negatively the construction industry perceives green roofs as an alternative to traditional roofing, the answers were typically dominated by negative bias. The interviewees regularly reiterated the industry's trepidation in accepting a relatively unproven technology.

Interviewee C: "Anything new scares people ... unless you have people that are really motivated by something else, change usually scares them away".

Interviewee F: "If I am honest, from my experience they [construction contractors] thought that green roofs were a bit painful ... the contractors thought 'well, what are we doing this for?'”.

Interviewee B: “Green roofs are not actively encouraged at the moment. I mean I think there is an awareness but I think planning won't drive this".

Interviewee D: "Sceptical. The immediate thing would be complexity—architects would think 'it is just another thing I have to detail'". 
Heller et al. [48] interestingly noted that designers are perceived to have the greatest ability (of construction professionals) to encourage greater uptake of green roofs. This raises an important point that, whilst landscape architects are typically in full support of green roof inclusions on a project [10], the construction professionals have a tendency to 'value engineer' the green roof out of the building design [48].

Interviewee E: “Landscape architects view green roofs very positively ... "

Interviewee A: "Typically, the key driver for those innovations on projects comes from landscape architects ... The landscape architects, you will find, are pretty good advocates for green roofs".

The view of [48] about green roofs typically being 'value engineered' out of construction projects was reaffirmed by the interview data.

Interviewee I: "It was how they structured the green roof into the renovation build so that there was no option of the green roof getting dropped off by budget blowouts, it couldn't even be engineered out".

\subsubsection{Project Champions}

Heller et al. [48] go on to mention that key stakeholders are required to champion the inclusion of green roofs in building designs to ensure that they are not "value engineered" out of a project. The interviewees, however, highlighted the impact of a client suggesting that builders or construction contractors do no tend to push for green roofs; instead, the onus is on the client side.

Interviewee I: “You have to have a champion for the project who drives it. So I don't think a builder will push it. I think you have to have a client that really wants it, and then it will happen".

Interviewee C: "Yeah, it is certainly client driven to a large extent".

Interviewee D: "You really need to dedicate a client that says 'I am going to do everything I can".

Interviewee E: "I'd say it is clients-people who have seen the concept and want to go on and try it".

This finding is in opposition to the view of Heller et al. (2014) [48], who consider landscape architects to be the typical champion.

\subsubsection{Potential of the Industry}

Despite the negative bias surrounding green roof technology at the moment, it was agreed with a great deal of recurrence that the local green roof industry has a realistic potential to evolve in some way in the years to come. Eight of the nine interviewees answered "yes" to the question "do you believe that there is a realistic potential for the local green roof industry to evolve in the future?" Answers ranged from "absolutely, I don't think we're anywhere close to the potential of green roofs in Australia" to "Yes, but it will require policy settings." One interviewee presented an opposing view and was particularly sceptical about the future of the Australian green roof industry, noting:

Interviewee D: “I don't think there is technical reasons that there isn't many green roofs.

I think there isn't enough demand or there isn't enough push". 


\subsubsection{What Needs to Change}

All of the interviewees who agreed that the local industry has potential to evolve went on to mention aspects of the industry that would need to change in order for progression to be possible. It was clear from these suggestions that there was one distinctive theme in advancing the industry, namely the role the government has to play: "government authority". At the federal level, cities' portfolios used to fall under the authority of the Department of Environment until the establishment of the federal government role of the Minister for Cities and the Built Environment in the third quarter of 2015, which was soon replaced in the first quarter of 2016 by another newly-created role of Assistant Minister to the Prime Minister for Cities and Digital Transformation. As far as it relates to the scope of this study, such a change highlights the enhanced notion in regards to greening cities because now, policy setting associated with the sustainability and resilience of Australian cities has entered the Prime Ministerial agenda. However, a closer look at the recent federal activities around green cities reveals that the Commonwealth government intends to transfer the responsibility in regards to green infrastructure to the local government. Accordingly, tangible actions, such as The Sydney Green Grid project and The City of Melbourne's Urban Forest Strategy, are initiated by local councils. The interviewees would tend to clarify the term "government authority" into a specific level: local, state or national. Most often, local or state governments were nominated to have the greatest potential in encouraging change. One interviewee went so far as to clarify that green roofs are not in the jurisdiction of the national government:

Interviewee C: "It is not a Commonwealth issue".

The primary theme of "government authority" appeared to be categorized into two distinctive sub-themes: "policy settings" and "government incentives".

Government Authority: Policy Settings

The existing body of Australian literature does not extensively discuss the role and the power that governments have to play in promoting the local green roof industry. Unlike many other advanced countries, like Singapore and France [49], Australia has very little, to no national-based policies or regulations regarding green roof implementation. The suggestion of [10], who note that "policy incentives developed to increase uptake", is supported with the data collected through interviews. Five of the nine interviewees flagged a change in policy settings to be the way forward for the local industry.

Interviewee C: "There may need to be a policy setting that supports it. I think that the policy environment has to change, around all of these things. If we don't [change] we are heading towards a train wreck".

Rayner et al. [10] further clarify and provide weight to this theme by explicitly stating that policy conditions have previously been restrictive for the local green roof industry; "While the absence of policy incentives is a barrier to the widespread uptake of green roofs ..."

The interviewees predominantly considered the main drivers for policy change to be the encouragement of green roof uptake and the subsequent reduction in cost.

Interviewee H: "Government policy setting would encourage more people to put green roofs up and therefore more people enter the market and they become cheaper".

Interviewee E: "Green roofs would become more regular, I suppose if the government made them conform to a certain level of environmental excellence".

These two identified drivers are directly supported in the statement of Rayner et al. (2010) [10], "recommendations and policies have not [previously] translated into financial incentives likely to stimulate the green roof industry or take the form of regulations that encourage the construction of green roofs". 
Cost is widely considered to be a very significant barrier for the implementation of green roofs across the local construction industry. Given the infancy of green roofs locally, the costs associated with such projects typically present as being too overwhelming for the private industry alone. Together, the established body of literature and interviews clearly indicate the need for government assistance in the form of policy settings. Once implemented, policy settings are able to indirectly reduce the cost of green roof technology as it becomes more "common practice".

Interviewee A: “I think that's important to understand, and without policy you are really relying on the market to drive it so, if people are more aware of it or they, I guess, see great examples of what that space [roof space] can be then the market will start to demand it".

Interviewee B: "So that will drive it and then the next step is for the local government to accommodate that. It is not a commonwealth or state issue, it is a local government issue. The local government needs to have appropriate policies which will facilitate that [driving force] to happen".

Interviewee H: "I keep coming back to how do we drive green roofs ... that is to construct more of them. How do we do that? We change our policy settings and there is a number of examples around the world where they can do that ..."

Importantly, a couple of interviewees flagged that the Green Building Council's Green Star rating system does not appropriately provide concessions for green roofs. The Green Star rating system, an initiative of the Green Building Council of Australia, is legislatively supported in Section J of the National Construction Code [50]. Two of the nine interviewees explicitly noted their concern over the "inequitable" point's concession for green roofs.

Interviewee H: "Green roofs are not really integrated into the Green Star systems so they [the key stakeholders of building that won an award for the most sustainable building in the world] wanted the green roof because it got the ecology bonus ... that was how they got the points".

Interviewee I: "You can get more points through having a bike rack".

Interviewee H: "I'd argue that those building stars don't acknowledge the multiple benefits of green roofs enough".

In direct comparison to the views presented by the above interviewees reflecting on the Australian Green Star rating system, a project manager who worked on a green roof project in London specifically linked the inclusion of a green roof to the achievement of a Building Research Establishment Environmental Assessment Method (BREEAM) Excellence rating.

Interviewee F: "I know in London, the only reason unfortunately, it's the reality though, the only reason why we did have a green roof on the project and spent the extra money was that it gave us a BREEAM 'Excellent' rating. It was a commercial incentive of leasing the building. The only reason we included a green roof was because it actually ticked a box and allowed us to get a BREEAM 'Excellent' rating. That additional rating was a huge driver for us to spend the money".

BREEAM is the United Kingdom's Environmental rating system for buildings. It is evident that in London, the BREEAM rating system played a significant role in the incorporation of a green roof in that specific project.

Legislative conditions and their influence on the construction of green roofs are distinctly different between the United Kingdom and Australia. The Green Star rating system, unlike the U.K.'s BREEAM system, provides very little commercial incentive to include green roofs within a building's design. 
Enhancing this finding, Rayner et al. (2010) [10] note that "policy makers are likely to be reluctant to include green roofs in building codes and planning guidelines until there is quality data assessing their costs and benefits in an Australian context". As a solution to this, two of the nine interviewees offered an "evidence-based approach" to be the way forward in allowing policy changes to be made.

Interviewee H: "I mean it's also going to be about an evidenced based approach looking at the benefits of green roofs".

Interviewee I: “ . . Melbourne Water [organization] . . . . they need the evidence base that enables them to argue for a policy change and the green roof industry".

\section{Government Authority: Government Incentives}

The central government's incentives toward green urban environment is associated with its ultimate impact on attracting highly skilled people who follow the improved lifestyle, rather than a vision that prioritises environmental programs. Envisaging New York as the model for further development of Sydney and Melbourne indeed demonstrates the loose position of greening in the national strategic plans [51]. In contrast, the central tenet of Green Plan of Singapore [52] is evolving into a city within a garden rather than revamping green canopies across a city to moderate the heat island effect or improve inhabitability. Data collected through this study also emphasizes the vision on perceiving the green roof as an integral component of the modern landscape.

Interviewee A: "More amenity that people can actually take advantage of is going to be the focus within developments".

A comparison between long-term green schemes envisaged by the Singaporean Government and their Australian counterpart highlights the sizable impact of governmental support on the uptake of green roof technology at a national scale. The Department of the Environment in Australia shares comparable accountability in regards to the urban environment as the Singaporean Ministry of the Environment and Water Resources does. However, contradictory to Singapore, the Australian framework does not target urban development directly. While the Sustainable Singapore Blueprint [53] envisions "a liveable and endearing home [embraced with] a vibrant and sustainable city", Australia reinforces "clean up and revegetate urban environments" as a secondary matter under the "clean land" section of "a cleaner environment" plan [54]. In other words, a lack of individual attention to "skyrise greenery" in the Clean Environment Plan compared to the Blueprint surfaces as one fundamental reason behind the significant difference in the level of green roof adoption between the two nations. Yet, deploying green technologies for retrofitting heritage buildings as highlighted by Sibley and Sibley (2013) [55] certainly is aligned with two out of four core priority areas, clean land and national heritage, targeted by the Australian Government. The challenges of adopting green roofs as a retrofitting technique leverage both the design and implementation of the project. However, interview results indicate that the difficulties in design outbalance construction problems in the case of heritage buildings, while the proportion is opposite for new developments.

Interviewee F: "I've worked with two green roofs on the project [in the capacity of project manager]. A green roof was on an existing building ... an existing buildings roof, it was a 150 year old building. Basically we had to change the structure of the roof component and obviously also the waterproofing and everything else that goes with it; so that was quite interesting. As I say I was involved in the design and implementation of that green roof; the implementation part of these projects is the easy bit. The second component of the project involved a large section of green roof to a new building. This was a lot easier in the sense that the design. The structural design was built in and it (green roof) wasn't retrofitted. That was really good." 
Financial incentives were additionally alluded to as being a potential way to evolve the local green roof industry. Whilst incentives were raised on a couple of occasions within the transcripts, the interviewees rarely went on to explain the role that incentives had to play.

Interviewee I: "Some sort of policy and being incentivized".

Interviewee F: "Green roofs would become more regular if the government incentivized it".

Interviewee E: "I think government incentives would help".

Interviewee G: "You need a series of incentives that encourage green roofs to happen".

An observation from within the data corpus was that whilst incentives do have some value in advancing the local green roof industry, that value is unspecified and appears to generally be less influential than other forms of government-driven change, such as the creation of new policy settings.

Interviewee D: “I don't think it is subsidies, I think that if there were requirements ... "

Interviewee A: "Well, I don't know if subsidies is the right approach. Policy can equate to subsidy in some ways..."

\subsection{Commercial Viability of Local Green Roof Industry}

Three distinctive critical factors, namely cost, education and government authority, all featured high rates of recurrence across the data corpus. When asked what the greatest barrier has been for local green roof implementation, six of the nine interviewees nominated cost as the most critical factor. Conversely to this, when asked how to overcome the barriers to local green roof technology, five of the nine interviewees suggested education to be a viable solution, and three interviewees noted the role that government authorities have to play in promoting the industry. The other, less significant critical factors were considered to be "value proposition" and "industry conservatism".

\subsubsection{Cost Implications}

It is widely known, in the literature and amongst practitioners, that the cost of green roof construction is more expensive than the cost of constructing a traditional roofing system [48]. What is not widely agreed upon, however, is why the cost of constructing green roofs is "indefensibly high", as noted by Forbes (2010) [33]. Without a doubt, the structural and non-structural components that go together to form the make-up of the green roof are more expensive than the construction materials of a typical roof. However, many prominent pieces of international literature agree that the greater initial investment of constructing a green roof as opposed to a traditional roof will be more than compensated by the savings on maintenance and the subsequent favourable lifecycle costings. Therefore, why then is the Australian construction industry, an industry inherently focused on the bottom line, not embracing green roofs in the way that international construction industries are? It predominantly comes down to risk. Of the six interviewees who noted cost as the greatest barrier to local green roof implementation, three of these interviewees inextricably linked the cost factor to risk.

The study of Rayner et al. (2010) [10] briefly addresses the effect of risk in green roof projects in Australia. Their study raises the concern that reliance on Northern Hemisphere research is problematic and highly risky, noting that such practices "May introduce unacceptable levels of risk and unnecessary expense to development projects considering green roofs". Contributing further to this finding, risk is not only incurred through reliance on international practices, but also inherently exists in the uncertainties of the local industry in its relative beginnings. Risk, as defined by the International Standards Organization [56], is "the effect of uncertainty on objectives". During the interview process, two interviewees labelled the construction industry as being "incredibly risk averse", whilst another one of the interviewees described the industry as being "conservative and loathed to change". This view is specifically supported by Heller et al. (2014) [48], who also note "builders are quite risk averse". More broadly than this though, the interviewee explained from personal experience; 
Interviewee C: "the Australian construction industry is incredibly risk adverse ... when you're talking about doing something different, because there is uncertainty that something could go bad, people do really get nervous because the risk is quite high ... the costs are quite high".

The interviewee additionally recognized that the cost of risk is not only monetary, but also transpires into other facets of a person's life, such as job security and reputation. The monetary impact of risk on green roof construction projects is borne by each project stakeholder-the main contractor, sub-contractors, suppliers and last, but not least, the client. In an interview with a project manager, it was noted that, for contractors, there was a cost associated with owning that commercial risk and uncertainty;

Interviewee F: "Owning the risk, the contractor is going to obviously cost that risk of an unproven technology".

Two of the three interviewees who linked cost to risk raised a discussion about contractual arrangements and noted that a project's contract has significant weight in determining the value of the risk and where it lies. One of the two above-mentioned interviewees, an academic, disclosed information on a green roof, public-private partnership project where the contractual arrangement focused on the effect of cost sharing.

Interviewee C: "Cost sharing between the design and construction components; there was risk sharing. It was a tender contract where if things went well and ran smoothly then the contractors got paid more, whereas if it didn't then the contractors would lose money. It gave the contractors the opportunity to deal a little bit more with uncertainty, otherwise these contracts they just get so tightly restricted..."

The interviewee focused on the partial freedom afforded to a specialist green roof, or construction contractor in the case of a contractual public-private partnership. Conversely to this, the project manager specifically highlighted the limitations of a lump sum contract in relation to green roof projects;

Interviewee F: "Especially in lump sum contracts, it comes back to the developer and to the client .... If you take on a lump sum contract you are taking on some risk and you price for that. Both at the contractor and subcontractor levels. If you are smart enough as a contractor to pass the risk on cheaply to the subcontractor then you would. But you also have to be there when things go wrong, so you have to tread carefully and negotiate".

The project manager suggested that contractors are inherently going to try and pass on as much commercial risk as possible; lump sum contracts were additionally labelled, by another interviewee, as being "so tightly restricted".

\subsubsection{Construction and Utilization}

The Hanging Gardens of Babylon are probably the most well-known adoption of the concept of green roofing throughout history. According to United Nations Educational, Scientific and Cultural Organization (UNESCO), the Persian Garden evolved in ancient Persia to honour sky, earth, water and plants. Interestingly, these core elements not only are entirely consistent with the modern environmental policy spotlight on air, land and water as advertised, for example, by the Australian Government, but also exclusively address greenery. Like its contemporary equivalent, a sophisticated irrigation system, as well as a consistent combination of vegetation facilitated the adoption of the nowadays called green roof a couple of thousand years ago [57]. Similarly, engineered solutions aligned with today's advanced construction procedures are required to allow widespread implementation of the green roof. The mounting mechanism, overlooking concerns, maintenance, constructability, flora 
selection and, more importantly, understanding the different performance aspects of the green roof are a few examples articulated by the participants.

Interviewee A: "There is a lot of engineers that are excited by the challenge of integrating things into their structures".

Interviewee B: “Whereas green walls [in contrast to green roofs] are straight forward, they are not visually intrusive and they are quite aesthetic".

Interviewee E: "An understanding of both the design but also the maintenance aspects of having plants on roofs (is essential to promote the technology)".

Interviewee F: "Risk is involved with the buildability of these things (green roof)".

Interviewee G: "Long, hot and dry summers all with little to no rain $(\ldots)$ is pretty challenging for any kind of plant."

Interviewee I: "The industry need to be more realistic about these things [performance of green roof]. We have evidence around the energy savings, we have evidence for biodiversity benefits. However, that far that the coolness (i.e., the reduction in the urban heat island effect) extends we don't know".

\subsubsection{Engineered Functions}

As the green roof becomes more prevalent, studies on the long-term performance of this technology emerge. While the positive impact of a green roof on urban storm water quality and quantity in the short term is well evidenced [58], Speak et al. [59] highlight the two-fold potential of the technology in dispositioning urban atmospheric pollutants, as well as becoming a source of legacy metal pollution in the long term. Advocating the positive side of the results reported by Speak et al. (2014) [59], one of the interviewees pointed out that customized green roof soil is able to accumulate nutrients available in the storm water to support vegetation growth.

Interviewee E: "It [the advanced green roof design] is a different system that essentially strips nutrients from storm water basically through soil".

Concerns regarding the lack of profound knowledge about the multifaceted performance criteria of the green roofs, specifically the shortage of longitudinal studies, have been echoed by the interviewees.

Interviewee A: “There hasn't necessarily been the data there before to really support the more humanistic elements of design (for green roof)".

Interviewee B: "The unknown of what comes with green roofs".

Interviewee D: “I don't think green roofs have been tested enough".

Interviewee E: "Landscape architects view green roofs very positively but maybe with a slight sense of trepidation regarding the number of unknown factors".

Therefore, it is interpreted that filling the knowledge gap in the area of green roofs enhances the competitive advantage of the technology in the construction market and eventually contributes to extended application. The result of studies on competing technologies, such as cool roofing [60], is a proper benchmarking tool to evaluate the competitiveness of the green roof against other advanced building technologies, particularly in regards to thermal insulation and energy performance. Pisello et al. [61] suggest that a combination of the two aforementioned technologies, the cool-green roof, is a promising solution where other invasive mitigation strategies are not practical to address the urban heat island phenomenon. 
Interviewee B: "The way that people are dealing with the heat island effect in infill cities is to increase the amount of greenery in the place and again that feeds into the green roof".

Interviewee C: "You have the heat island effect also." The interviewee explained that his source is common knowledge and not actual measurement "Aside from my government stuff around sustainability projects and that sort of thing".

Interviewee E: "Green roofs ( . . ) could alleviate the Heat Island Effect. Based on the data I collected, it looked like the green roof would actually reduce the energy bills of the shopping centre significantly, almost as much that it would pay for the construction, and then also double the retail area as well. So, yeah there is really good possibilities for green roofs in that sense".

Interviewee G: "In my role as mayor, we've been looking at the role that green roofs and green walls can play in terms of urban design in the CBD primarily and around looking at the Heat Island Effect but also around urban biodiversity".

$\mathrm{Li}$ and Norford [62] demonstrated that with the city-scale implementation, the two technologies complement each other, as a cool roof is more effective during the daytime and a green roof adapts to the cooling cycle at night-time.

Interviewee H: "If you want to reduce the urban heat island effect you need an irrigated green roof on the hottest days. Our substrates here store a lot of heat and they'll re-radiate that heat at night but they won't store a lot of heat if you irrigate it because that energy will be evaporated off".

\subsubsection{Education}

When asked whether or not there was a viable way to mitigate the challenges presented by green roof technology in Australia, five of the nine interviewees suggested that education has a significant scope and leverage for improving the current state of the local green roof industry. Through the process of conducting interviews, the term "education" was found to be synonymous with "research" and "raising awareness".

It was found that every stakeholder group, from project managers to subcontractors to clients, generally requires some form of further education about green roofs if the local industry is to progress in the future. The existing body of local literature supports this finding, in recognizing that the research gap stands as a barrier to more widespread use of green roofs in Australia [63,64].

Interviewee E: "Well really it is education and greater (more) information through the construction industry, builders and also the government at all levels. I think that is quite important".

Of particular note was an outlying, but informed response, which noted the education programs currently existing within the industry relating to "green roofs". Australasia seminars and workshops are not "hitting" those with the power to make the required changes in the industry. That is, decision makers rarely have enough information or education regarding the logistics of how green roof projects work and thereby do not opt to undertake such work given the uncertainty and associated risks.

Interviewee E: "Education isn't perhaps available to the people in decision making positions. If people have been in their industries for 10-15 years and are at the director level-they are the people that really drive a lot of change. Something that I have found with green roof infrastructure projects is ... it is not that these people do not want to implement these things, it is that they weren't taught how to do them". 
In recognizing that people in upper management positions require greater education and information about green roofs, the need for education for the other constituents in a supply chain is not to be ignored. Of the nine interviewees, five recognized that education is required to increase awareness and subsequently decrease the inherent uncertainty of current green roof projects.

Interviewee C: "It comes down to research. People who are doing work around bedding down that uncertainty would then share the info and take some risk out of them (green roofs)".

\subsubsection{Government Authority}

A third of the interviewees recognized that government authorities, whether they be local, state or national, have the ability to mitigate some of the challenges identified for the local green roof industry. These participants raised a small range of government-driven-specific solutions; "the right research and the right incentives", "the legislative side of things" and "demonstration projects".

Governments at all levels are empowered, in some way, to make a positive change to the local green roof industry. As evidenced in more than one interview, the government was identified as the stakeholder group that is needed to drive the local green roof industry. Private companies alone are typically unwilling to take on green roof projects given the current commercial risk; herein lies the need for government assistance.

Interviewee G: "There is an important role for both government at the national level but also at the local level to provide an example of how we design our cities and I think it needs that level of support because this is not going to be something that many companies will do on their own".

Interviewee E: “Certainly developers aren't so keen to do demonstration projects because of the risk and monetary expenses".

The government is a unique stakeholder in the construction industry and is perhaps the best equipped at dealing with commercial risk.

Interviewee G: "I think this is where governments have a role to play in terms of having the right incentives and the right research happening to enable these things to cross from 'risky' to 'mainstream'".

Public-private partnerships present as an opportunity for the inclusion of green roofs within building designs. Of course, the approach is not "one size fits all"; not every building constructed under public-private partnerships will be able to incorporate a green roof practically. However, some success has been shown in projects with these contractual arrangements due to cost-sharing and risk sharing between the government and private industry.

Interviewee C: “Well the reason why this project was even able to go into that territory is because they did a public-private partnership type thing so there was cost sharing between the design and construction components; there was risk sharing. It was a tender contract where if things went well and ran smoothly then the contractors got paid more, whereas if it didn't then the contractors would lose money. It gave the contractors the opportunity to deal a little bit more with uncertainty ..."

Additionally, government-led demonstration projects or "pilot projects" were regularly raised as a solution in removing some of the risk factors and associated expenses of current green roof projects.

Interviewee C: "Yes, that's where pilot projects can be really good. Pilot projects would allow policy makers to get comfortable with 'ok, maybe we can change the rules'". 
Interviewee B: "People are incredibly risk averse so yes, pilot projects are good at creating a bit of comfort".

Interviewee F: “In time it will become more common place and to do that you have to go back to the legislative side of things, making green roofs something that people want to do".

The proactive strategy applied in Singapore removes the need for further reactive efforts to rectify issues associated with the micro-climate formed by density living. Gliedt and Hoicka [65] share a similar notion categorizing green roofs as an "environmental sustainability initiative", rather than a "financial investment". Actually, from a risk management perspective, Singaporean policy makers have targeted the root causes of excessive heat amassed in building materials by looking at natural greenery as a piece of infrastructure, rather than shaping policy around responsive actions to improve urban residents' wellbeing compromised by overdevelopment. Therefore, a vertically-inclusive policy mechanism is required to facilitate long-term cooperation in all tiers of government in order to transform the development of green cities in Australia. For example, land value capture models, which intend to partially shift the cost of infrastructure development to surrounding land owners that benefit from the development potentially, can be adopted to promote the diffusion of green roof technology within the local construction industry subject to the fundamental change in regards to accepting urban canopies as infrastructure. Such an interpretation implied in guidelines and policies issued by local governments needs to be disseminated from the bottom toward to the top of the regulatory system in Australia. Both the Green Roofs Policy and the Walls Policy issued by the City of Sydney [66] in 2014 and Victoria's Guide to Green Roofs, Walls and Facades [67], issued by four inner Melbourne local governments in 2013, approach the green roof as a component of "green infrastructure". Victoria's Guide highlights the fundamental need for this type infrastructure to aid urban cooling, reduce energy consumption, manage storm water, improve air quality and enhance wellbeing. Sydney's policy further discusses the benefit of the green roof as a facility for food production and absorption of carbon dioxide, a catalyst of solar panels' performance, as well as a solution to address biodiversity.

\subsection{Green Roof Promotion}

Through the interviewing process, green roofs were shown to be familiar to a range of stakeholder groups within the construction industry. A number of construction sub-industries are "aware" of the concept of green roofs, but know little about the technicalities of the roofing system.

Interviewee A: "Inherently it requires a lot more technical input ... That is why these things can be viewed by people who have never done green roofs as being really difficult things to do".

Whilst many industry stakeholders are "aware" of the green roof concept, private clients, governments and, to a lesser degree, industry bodies (e.g., Green Roofs Australasia or the Australian Institute of Landscape Architects) were noted as being the biggest drivers for local green roof technology. When asked who the biggest driver for green roofs in Australia was, four interviewees noted "private clients", three interviewees noted "government authorities" and the remaining two interviewees suggested 'industry bodies' to be the biggest driver.

\subsubsection{Private Clients}

Much of the current green roof demand in Australia has seemingly come from proactive private clients.

Interviewee B: "It is going to be the individuals and we are seeing it now. They will drive that, they've been driving it anyway".

Interviewee F: "Obviously demand will drive these things". 


\subsubsection{Government Authorities}

Once there is sufficient demand from the private clients within the industry, many interviewees agreed that the responsibility then becomes that of the local government and policy makers. The onus turns to the policy makers who, in order to promote the industry, must create policy settings that accommodate and encourage the demand from private clients. The government authority's role is one of facilitation, rather than promotion.

Interviewee A: "I guess through other mechanisms and procedures the government is able to make the case for green roofs be important".

The importance of an evidence-based approach to policy making was highlighted by two interviewees.

Interviewee H: "They [authorities] need the evidence base that enables them to argue for a policy change..."

Interviewee G: "I mean it's also going to be about an evidenced based approach looking at the benefits of green roofs..."

\subsubsection{Industry Bodies}

Interviewees generally perceived one particular industry body, which cannot be named for anonymity reasons, as having a positive influence on the development of the local green roof industry. As one interviewee divulged, the industry body is assumed to undertake media releases and training workshops as a means of promoting the local industry.

Interviewee E: "I guess they do media releases. That would be a big one and also training workshops".

It was the general consensus amongst interviewees that the industry body is tasked with providing the promotion of the industry in its 'early-days', that is until the private industry more widely adopts the technology.

Interviewee D: "They [the industry body] push it until green roofs are taken up by a wide part of the construction industry ..."

Interviewee G: "The industry body. They are certainly pushing them".

Heller et al.'s [48] focus group study found that "professional bodies have a role to play with the provision of best practice guidelines and notes for members so that they are able to learn about the technical issues and factors to take into account in decision making".

Despite some interviewee's support for the industry body, concerns have been raised about its efficiency in promoting the local use of green roof technology. Two interviewees, who have previously had working relationships with the organization, explicitly labelled the unnamed industry body as being "totally defunct".

Interviewee I: "We don't take (the industry body) with much weight, they are defunct."

Interviewee $\mathrm{H}$ : "It is not actually a functional organization at all. It is pretty much, not an organization, they don't do anything. I wouldn't use their membership as being something that indicates "involvement" because I know a number of people who do green roof stuff that are not necessarily members of (the industry body), because it is totally defunct".

Interviewee I: "People do not see the benefit in being a member".

Given the specificity of these comments, further investigation into the role of industry bodies in the Australian green roof industry would be of significance. 


\section{Verifying the Consistency of the Findings and the Collected Data}

As discussed, the green technology adoption in Australia is significantly new, and consequently, the market is comparatively small. Therefore, the data collected through the interviews can confidently be used to draw a picture of the market. According to the nature of the interviews, some of the participants may have not commented on some particular topics, due to a lack of knowledge, for example. The authors have tried to reflect where the majority of participants consistently agree/disagree with something. However, where opposing comments have been noticed, existing literature has been cited to demonstrate that inconsistency is inherent to that particular topic and does not compromise the statistical soundness of the results. However, in order to verify that the results are reflecting participants' input, free of investigator bias, this study applies a novel statistical approach. The intention is to ensure that the articulated findings are consistently supported by the participants' input. To do so, according to the structure of the paper, we divide the current manuscript into three categories corresponding to Sections 4.1-4.3. Then, we extract a library of keywords from each category and use them to develop three histograms of common vocabularies for each individual interview. This means that each interview is analysed against the libraries representing the three categories. We will then test the consistency of the histogram representing each category and the ones obtained from each distinct interview. The rationale behind using this manuscript to develop the library is that it is extracted from all interviews inclusively. Therefore, the procedure of extracting the findings is verified to be statistically sound, if the comparison of the final product and each interview manuscript results in the conclusion that both are comprised of the same building elements. This is, of course, shown by testing the hypothesis that the two histograms are drawn from the same distribution. It must be highlighted that this procedure only verifies that the results emerged from the interview data, but it does not measure the level of agreement/disagreement on a topic. For example, the outcome of this statistical analysis is an indicator of the significance of the impact of one particular interview on the overall conclusions presented in each category.

An online text analyser called VOYANT [68] has been used to screen the Results Section of this manuscript. The components consisting of literature surveys were deliberately included in the input as they are mainly used as the grounds for triangulation to shape different classifications emerging from interview data. In other words, mining the reference library from the selected pieces of literature together with interview results enhances the reliability of the discussed findings in terms of highlighting any potential controversy between the accepted trend in the body of knowledge and what was outlined in the interviews. Given $N_{i}$ as the total number of words and $n_{i}$ as the number of unique words in each category, the average occurrence of one word in each category, $\bar{n}_{i}$, can be calculated.

$$
\bar{n}_{i}=\frac{N_{i}}{n_{i}} \text { for } i=1,2,3,
$$

$\bar{n}_{i}$ is then used to assign an "impact" index, $I_{i, j}$, to each unique word, $u_{i, j}$, in different categories. Note that $j=1, \ldots, n_{i}^{\prime}$ for each $i$; with $j=1$ representing the highest frequency. The "impact" of each word is assumed to be directly correlated to its frequency as long as the word passes the first filtration process to confirm its relevance to provide a discussion in the context of green roofs. The modified number of words in each category is represented by $n_{i}^{\prime}$. To remain on the conservative side, words such as green, roof(s), etc., that inevitably are used when discussing green roofs are excluded from the libraries. Including these words will increase the likelihood of verifying the consistency, while it does not exist, therefore, decaying the power of the test.

$$
I_{i, j}=\frac{n_{i, j}}{\bar{n}_{i}}
$$

where $n_{i, j}$ is the word count associated with word $u_{i, j}$. The impact index enables us to classify unique words used in the paper into three tiers: 
a. Uniquely important: referring to words that exclusively represent one category. For example, the word "risk" with $n_{2,1}=31$, resulting in an impact index of 9.6, is strongly correlated with the content of Category 2 only.

b. Equally important: covering words with a high impact index in all four categories. For example, the word "local" with $I_{1,4}=5.2, I_{2,5}=5.0, I_{3,3}=3.3$ falls in this tier.

c. Mutually important: including words with a high impact index in more than one category, but not all three. For example, the word "client(s)" with $I_{1,13}=1.5$ and $I_{3,5}=2.5$ contributes to both Categories 1 and 3.

The four reference libraries providing the basis for the consistency test are listed in Table 1.

Table 1. Keyword distributions in the three reference categories.

\begin{tabular}{|c|c|c|c|c|c|c|c|c|c|}
\hline \multirow{2}{*}{ Reference Library } & \multicolumn{3}{|c|}{ Category 1} & \multicolumn{3}{|c|}{ Category 2} & \multicolumn{3}{|c|}{ Category 3} \\
\hline & Rank & $\mathbf{I}$ & Tier & Rank & $\mathbf{I}$ & Tier & Rank & $\mathbf{I}$ & Tier \\
\hline Australia(n)/national & 3 & 6.8 & c & & & & & & \\
\hline $\begin{array}{c}\text { Authority(s) } \\
\text { Benefit(s) }\end{array}$ & 11 & 1.8 & c & & & & 9 & 1.2 & $c$ \\
\hline Body(is) & & & & & & & 2 & 5.7 & $c$ \\
\hline Change(s) & 6 & 4 & a & & & & & & \\
\hline Client(s) & 13 & 1.5 & c & & & & 5 & 2.5 & c \\
\hline Commercial & & & & 19 & 1.6 & a & & & \\
\hline Construction & 7 & 4 & c & 4 & 5.3 & c & & & \\
\hline Contract(ual) & & & & 12 & 2.8 & a & & & \\
\hline Contractor(s) & & & & 7 & 4.3 & a & & & \\
\hline Cost/Money & & & & 3 & 6.2 & c & & & \\
\hline Demand/Need & 12 & 1.8 & c & 18 & 1.9 & c & 7 & 2 & c \\
\hline Design & 10 & 2.2 & c & 15 & 2.2 & c & & & \\
\hline Development(s) & & & & & & & & & \\
\hline Education/Knowledge & & & & 8 & 4 & c & & & \\
\hline Energy & & & & 20 & 1.6 & a & & & \\
\hline Environment(al)/Sustainable(ity) & & & & & & & & & \\
\hline Government(s) & 2 & 7.1 & c & 6 & 4.7 & c & 6 & 2.5 & $c$ \\
\hline Heat & & & & 9 & 3.4 & a & & & \\
\hline Incentive(s) & 8 & 3.7 & a & & & & & & \\
\hline Industry(s) & 4 & 6.2 & b & 2 & 6.5 & $\mathrm{~b}$ & 1 & 9.4 & $\mathrm{~b}$ \\
\hline Island & & & & 16 & 2.2 & a & & & \\
\hline Local & 5 & 5.2 & $\mathrm{~b}$ & 5 & 5 & $\mathrm{~b}$ & 3 & 3.3 & $\mathrm{~b}$ \\
\hline People & & & & 10 & 3.1 & a & & & \\
\hline Policy(s) & 1 & 7.7 & a & & & & & & \\
\hline Potential & 9 & 2.8 & a & & & & & & \\
\hline Private & & & & 17 & 2.2 & a & 4 & 2.9 & $c$ \\
\hline Risk(s) & & & & 1 & 9.6 & a & & & \\
\hline Technology(s) & & & & 13 & 2.8 & a & & & \\
\hline Uncertainty(s) & & & & 14 & 2.5 & $\mathrm{a}$ & & & \\
\hline Urban & & & & 11 & 3.1 & a & & & \\
\hline Value & 14 & 1.5 & a & & & & & & \\
\hline
\end{tabular}

Determining the number of words in each bin, a histogram can be created to visualize the distribution of the key words in each interview. In our case, we are only interested in comparing the shape of each interview's histogram with the one obtained from the reference library. Accordingly, we test the null hypothesis that the densities of the two histograms are bin-by-bin equal. The null hypothesis is tested against the hypothesis indicating that the densities of the two histograms are not bin-by-bin equal. Attention is required that we are interested in comparing the bin-by-bin means of the two histograms. For this reason, we normalize histogram bin contents before calculating the statistic for the chi-square test. The normalization is carried out using the ratio of the total number of words included in the histogram being tested over the word density of the reference library. For example, when testing the consistency of Section 4.1 of this manuscript and Interview A with a total of 183 and 81 words in their histograms, correspondingly, the number of words in each bin of the reference histogram is normalized by multiplying it by 0.44 , which is $\frac{81}{183}$. This way, a normalized histogram is available to be tested against each interview's histogram for the purpose of consistency verification. The test statistic [69] is calculated using Equation (3).

$$
T=\sum_{t=1}^{n^{\prime}} \frac{\left(s_{t}-v_{t}\right)^{2}}{s_{t}^{2}+v_{t}^{2}},
$$


where $s_{t}$ and $v_{t}$ are the number of words in each bin of the histogram being tested and the normalized reference histogram, accordingly. Using the same hypothesis as mentioned, the chi-square test will be run 27 times to compare each interview against the three reference libraries. However, it is very unlikely to get the null hypothesis accepted without eliminating the "deficiency" in histogram being tested. "Deficiency" refers to bias in the word distribution induced due to the personal preference of the interviewees that, to some extent, is inevitable without the intervention of the interviewer to trigger the use of particular words. Of course, because intervention clearly compromises the reliability of the data collection, deficiency has to be allowed, but filtered during the consistency test. Deficiency surfaces in terms of a relatively more significant contribution to the test statistic. Referring to Table 2, the words "value" and "design" collectively contribute 13 points to the calculated 20.3 statistic. Hypothesis testing using this statistic will result in the rejection of the null hypothesis while a closer look at the data contradicts this outcome. The impact index of all words in the reference histogram add to 56.3. Excluding "value" and "design" still contains 93.4\% (cumulative sum of 52.6) of the total impact compared to the initial setup. Interestingly, excluding these deficiencies results in enough evidence to accept the null hypothesis and to confirm the consistency of Interview A and Section 4.1. In other words, the fact that an interviewee has not used specific keywords does not necessarily mean that $\mathrm{s} /$ he has not sufficiently used the remaining keywords to assure consistency. As explained, the overall impact can be used to assess links to the remaining keywords. However, in the case that removing deficiency significantly reduces the impact, as well, then the null hypothesis must be rejected.

Table 2. Details of hypothesis testing and the filtration of deficiency (Interview A against Section 4.1).

\begin{tabular}{|c|c|c|c|c|c|c|}
\hline Keyword & $\begin{array}{l}\text { Interview } \\
\text { Histogram }\end{array}$ & $\begin{array}{l}\text { Reference } \\
\text { Histogram }\end{array}$ & $\begin{array}{l}\text { Modified } \\
\text { Reference }\end{array}$ & $\begin{array}{l}\text { Contribution } \\
\text { to Statistic }\end{array}$ & $\begin{array}{l}\text { Impact } \\
\text { Index }\end{array}$ & $\begin{array}{l}\text { Deficiency } \\
\text { Excluded } \\
\text { Impact }\end{array}$ \\
\hline Australia(n)/national & 10 & 22 & 9.7 & 0.003 & 6.8 & 6.8 \\
\hline Authority(s) & 2 & 6 & 2.7 & 0.092 & 1.8 & 1.8 \\
\hline Change(s) & 3 & 13 & 5.8 & 0.866 & 4 & 4 \\
\hline Client(s) & 2 & 5 & 2.2 & 0.011 & 1.5 & 1.5 \\
\hline Construction & 2 & 13 & 5.8 & 1.818 & 4 & 4 \\
\hline Demand/Need & 1 & 6 & 2.7 & 0.750 & 1.8 & 1.8 \\
\hline Design & 11 & 7 & 3.1 & 4.429 & 2.2 & - \\
\hline Government(s) & 10 & 23 & 10.2 & 0.002 & 7.1 & 7.1 \\
\hline Incentive(s) & 2 & 12 & 5.3 & 1.500 & 3.7 & 3.7 \\
\hline Industry(s) & 7 & 20 & 8.9 & 0.216 & 6.2 & 6.2 \\
\hline Local & 3 & 17 & 7.5 & 1.945 & 5.2 & 5.2 \\
\hline Policy(s) & 11 & 25 & 11.1 & 0.000 & 7.7 & 7.7 \\
\hline Potential & 3 & 9 & 4.0 & 0.139 & 2.8 & 2.8 \\
\hline Value & 14 & 5 & 2.2 & 8.569 & 1.5 & - \\
\hline \multirow[t]{2}{*}{ Sum } & 183 & 81 & 81 & 20.34 & 56.3 & 52.6 \\
\hline & & & & $\begin{array}{l}\text { Impact } \\
\text { Covered }\end{array}$ & $100 \%$ & $93.4 \%$ \\
\hline
\end{tabular}

Knowing that the data have been collected through interviews, a 50\% confidence level seems reasonable to verify the consistency of findings and the interview data. Setting a higher confidence level is not favourable, because the objective of the data analysis is not to copy and paste the interview data, but is to extract evidence from the data corpus. A confidence level below $50 \%$, on the other hand, increases the probability of incorrectly verifying consistency. Referring to the results of the consistency tests summarized in Table 3, it can be concluded that discussions and conclusions provided in this paper are all consistent with the content of the interviews with at least $50 \%$ confidence, except one instance. Of course, Table 3 can be consulted to determine the significance of different interviews' inputs on various conclusions made in the paper. For example, Interview $\mathrm{H}$ has the highest impact on determining the state of the industry; Interview $\mathrm{G}$ is the champion in predicting the commercial viability of the green roof; and Interview A has provided the most insight into the promotion strategies of the technology. 
Table 3. Outcome of the consistency test of the interviews and their associated impact.

\begin{tabular}{lcccc}
\hline & & \multicolumn{3}{c}{ Insight: Impact (Confidence Level) } \\
\cline { 3 - 4 } & & State of the Industry & Commercial Viability & Promotion \\
\hline \multirow{5}{*}{ Interview } & A & $0.93(0.77)$ & $0.64(0.56)$ & $0.92(0.62)$ \\
& B & $0.48(0.53)$ & $0.69(0.56)$ & Tie $^{1}$ \\
& C & $0.88(0.51)$ & $0.92(0.50)$ & $0.50(0.56)$ \\
D & $0.53(0.51)$ & $0.72(0.50)$ & $0.69(0.77)$ \\
& E & $0.80(0.51)$ & $0.66(0.61)$ & $0.64(0.58)$ \\
F & $0.58(0.59)$ & $0.61(0.53)$ & $0.61(0.61)$ \\
& G & $0.86(0.86)$ & $1.00(0.72)$ & $0.72(0.73)$ \\
& H & $0.97(0.72)$ & $0.73(0.59)$ & $0.61(0.61)$ \\
I & $0.81(0.59)$ & $0.72(0.65)$ & $0.74(0.52)$ \\
\hline
\end{tabular}

${ }^{1}$ A tie that happens when eliminating deficiencies does not lead to any confidence level higher than 0.50. Therefore, Interviewee B's input inn Section 4.3.1 must be used with more care.

\section{Conclusions}

The Australian construction industry, not dissimilar to the global construction community, is faced with the ever-present concern over the sustainability of development practices. Established literature and examples of functioning green roof systems prove that the technology has the potential, when used correctly, to be a sustainable means of development. Despite their benefits, the potential of green roofs in the Australian construction industry is currently unrealized. A vast proportion of Australian-based green roof literature concerns the horticultural or scientific aspects of green roof technology. The construction perspective of this study therefore stands to add value to the existing literature.

Through the research process, it was decisively found that the Australian construction industry (holistically) approaches green roof technology with scepticism and trepidation. The interviewee's responses demonstrated that the local construction industry's perception of green roofs is, in one way or another, dominated by negative stigmas. Representative of these generally-negative perceptions, terms such as "painful" and "complex" were used to explain people's first-hand experience or perception of local green roof projects.

However negative the current perceptions of green roofs are in the Australian construction industry, it was found, with overwhelming support, that green roof technology does have the potential to evolve at some point (unspecified) in the future. A dominant majority of the interviewees (eight of nine) claimed that the "local green roof industry has the potential to evolve". From these responses, "government authority" was repeatedly suggested as the key stakeholder capable of making the required changes in order to improve the current state of the industry. Governments were noted to have the power to change policy settings, which was suggested to be the first and significant step in improving the local green roof industry. The importance of policy settings was additionally addressed and supported in key Australian literature.

Two interviewees clarified the 'policy' aspect of governmental power to be, for example, energy efficiency legislation, such as the Green Building Council of Australia's Green Star Ratings. The Green Star rating system was found to inappropriately recognize the sustainability benefits of including green roofs in building designs. To heighten this apparent legislative shortfall, one interviewee reflected on the efficiency of the United Kingdom's BREEAM system in promoting the use of green roofs. It was found that the BREEAM system directly encouraged developers to spend additional funds to include a green roof within a building's design in return for a favourable BREEAM rating, such as BREEAM "Excellent".

Cost was found to be, by far, the greatest barrier to more widespread implementation of green roofs in the Australian construction industry. Six of the nine interviewees nominated cost as being the most apparent barrier, and this finding is extensively supported in the Australian-based literature. Of the six interviewees who noted cost to be the most critical factor affecting green roof implementation in the local industry, a further three noted an inextricable link to commercial risk. The construction 
industry was labelled, by two of the interviewees, as being "conservative and loathed to change", as well as 'incredibly risk averse', a view shared by the established literature.

The monetary risk of green roof projects is typically born by each of the project stakeholders; though, it was found that contractual arrangements, such as public-private partnerships (featuring cost sharing) are a way of "managing" risk levels. Conversely, lump sum contracts were labelled as being "so tightly restrictive" when considered in the context of green roof projects.

Education, or more appropriately, a relative lack-thereof, was found to be another critical factor affecting the implementation of green roofs in the Australian construction industry. Education was suggested by five of the nine interviewees as having significant scope to improve the uptake of local green roof projects. Each stakeholder group, be it the project managers, subcontractors or clients, would gain from further education in the field of Australian green roofs. Insightfully, one interviewee noted education to be ill-directed, whereby upper-management, those with the power to drive change, are not taught how to successfully undertake a green roof project. It would therefore appear that green roofs are, in some cases, 'overlooked' due to uncertainty and ill-directed educational programs.

The third factor considered as being critical by the interviewees was the role of the government authority, not only promoting the industry through policy settings, but also conducting 'pilot projects'. A third of interviewees noted the government to be a critical factor within the industry; especially in conducting demonstration projects within the public realm to reduce the uncertainty associated with green roofs currently.

It was found that private clients tended to be the stakeholder group that is currently driving the green roof industry here in Australia. Environmentally-conscious and proactive private clients are interested in the concept of green roof technology given the commercial incentives or marketability aspects. It was noted that despite the private industry's interest in green roof technology, greater assistance is needed. Assistance was specifically noted to be adapted to policy settings (government action) or greater promotion from the industry bodies.

Once people start to demand green roofs, through whatever motives or reasons, the onus turns to the policy makers who have the power to facilitate their uptake. Through legislative mechanisms, the government is able to make the case for green roofs important. Highly regarded literature agrees and further finds that changes to Australian legislation, be it building codes or planning guidelines, must be based on comprehensive research; this is the realm of industry bodies.

It was found that the role of professional bodies is to provide best practice guidelines and members' support/education. While this, in theory, is the function of industry bodies, specific concerns were raised about their efficiency. Whilst there was some support for industry bodies, two interviewees specifically challenged the role that one industry body is currently playing in the industry. Those interviewees who supported the work of the industry body, to the knowledge of the researcher team, have not had close dealings with the unnamed organization. Conversely, the two interviewees who expressed negative comments have previously had working relationships with the organization. Opinions on the industry body are divided, with further investigation into the role of industry bodies within the Australian green roof industry being a topic with further research potential.

Further research into the effect of policy changes on the cost of Australian green roofs, an analysis of the role of industry bodies in the promotion of green roofs and a lifecycle cost benefit analysis of green roofs in an Australian context are some studies that would all be of significant value for the local green roof industry. Studies that comparatively assess the cost of green roofs in Australia to the cost of traditional roofing systems would be invaluable in allowing the industry to see the potential cost savings of green roofs, which have clearly been demonstrated in the international arena. Additionally, alternative frameworks for sustainable building funds will need to be explored in further depth.

Acknowledgments: The open access processing fee has been covered through the supportive funding provided by the School of Built Environment at Curtin University.

Author Contributions: Nicole Tassicker and Payam Rahnamayiezekavat have designed the research and the interviews. The interviews have been carried out and initially analysed by Nicole Tassicker. The results have been 
finalized through discussion between Payam Rahnamayiezekavat, Monty Sutrisna and Nicole Tassicker. The statistical analysis has been designed and implemented by Payam Rahnamayiezekavat. The manuscript has been structured and reviewed by Payam Rahnamayiezekavat and Monty Sutrisna.

Conflicts of Interest: The authors declare no conflict of interest.

\section{Appendix A. Interview Questions}

\section{INTERVIEW QUESTIONS}

\footnotetext{
Section 1: The Future of the Australian Green Roof Industry

1a. Do you believe that the Australian green roof industry has a realistic potential to evolve and adapt in the years to come?

1b. What would be required to happen to bring about this positive change? (i.e., technological change, government subsidies/incentives etc.)?
}

\footnotetext{
Section 2: Barriers to Green Roof Implementation in Australia

2a. What would you consider to be the greatest barrier to widespread implementation of green roofs? Is it a stubbornness to change within the industry, cost etc.?

2b. Is there a viable way to mitigate the challenges presented by this barrier, or is it too great of an issue to overcome?
}

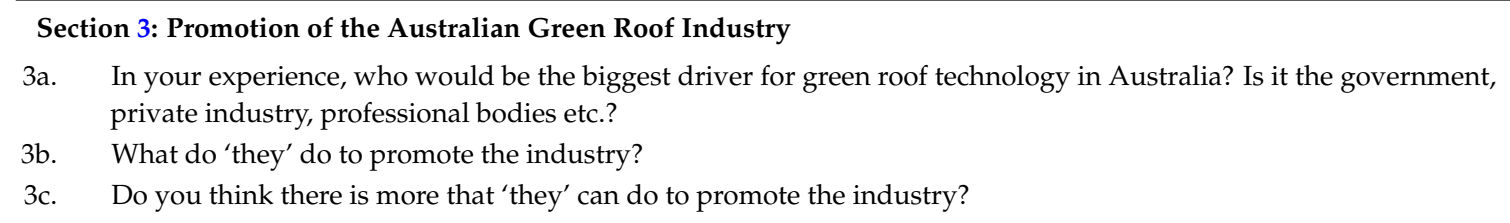

\section{Section 4: Demand for Green Roofs in Australia}

4a. How would you describe the construction/design industry's perception of green roofs? Are green roofs actively encouraged throughout the industry?

Design Rationale: The first section; "The Future of the Australian Green Roof Industry", aims to assess the likelihood of advancing the local green roof industry and thereby relates directly to the first objective of this study. Questions 1a and 1b purposely assess the interviewee's opinion of the industry's potential, so that the ensuing questions could be posed in a way to extract greater information on the matter. For example, if an interviewee considered there to be minimal potential for the green roof industry in Australia, then the following sections of questions would be used to assess how or why they have formed that opinion, and vice versa.

"Section 2: Barriers to Green Roof Implementation in Australia" focusses on the critical factors affecting green roof implementation and how these are impacting the local industry; the second objective of the dissertation. Questions $2 a$ and $2 b$ feature an amount of inherent bias, however, focussing on discovering what have been the constraining factors in the past and how these factors can be mitigated going forward.

"Section 3: The Promotion of the Australian Green Roof Industry" inherently focusses on the positive side of the local green roof industry; a question to directly offset the negative bias of Section 2 . Questions $3 \mathrm{a}, 3 \mathrm{~b}$ and $3 \mathrm{c}$ critically analyse the sources of green roof promotion in the local industry and determine what each of the nominated stakeholders are currently doing within the industry; the third objective of the dissertation.

"Section 4: Demand for Green Roofs in Australia" directly addresses the level of green roof awareness and willingness that people perceive within the construction-related industries; a topic relevant to all of the objectives of the dissertation. Question 4 a enabled significant insight to be gained into the 
current state of the local green roof industry, thereby allowing the researcher to objectively gauge the progression of the industry.

After the "structured" components of the interview had been discussed, the researcher then asked the lead in question, "is there anything else that you would like to add, or feel that I have missed?" Participants were afforded the opportunity to further explain aspects of the local green roof industry and to make recommendations or comments about the study.

\section{Appendix B}

\section{PROFILE OF INTERVIEWEES}

\begin{tabular}{|c|c|c|}
\hline Pseudonym & Gender & Background with Green Roofs \\
\hline Interviewee A & Male & $\begin{array}{l}\text { - Practicing landscape architect; } \\
\text { - } \quad \text { Practiced internationally for a number of years; } \\
\text { Porking knowledge of Australian green roofs, particularly in } \\
\text { Perth; and } \\
\text { - Worked as a green roof consultant on the Fiona Stanley Hospital } \\
\text { and } 140 \text { William Street projects in Perth. }\end{array}$ \\
\hline Interviewee B & Male & $\begin{array}{l}\text { Experience as a consultant in the private industry in regards to } \\
\text { sustainability and town planning. }\end{array}$ \\
\hline Interviewee C & Female & $\begin{array}{l}\text { - } \quad 10 \text { years' experience; } \\
\text { - } \quad \text { Studied a green roof engineering firm's performance. }\end{array}$ \\
\hline Interviewee D & Female & $\begin{array}{l}\text { - Academic background in the field of architecture; and } \\
\text { - Involved in construction of a small-scale green roof in the 1970s. }\end{array}$ \\
\hline Interviewee E & Male & $\begin{array}{l}\text { - } \quad \text { Practicing landscape architect; } \\
\text { - } \quad \text { Royal Melbourne Institute of Technology (RMIT) Qualified; } \\
\text { - } \quad \text { Gesearch projects into historic green roofs in Perth; and } \\
\quad \text { experience in Melbourne. }\end{array}$ \\
\hline Interviewee F & Male & $\begin{array}{l}\text { - } \quad \text { Practicing consultant; } \\
\text { - } \quad \text { Econtin University Construction Management and } \\
\text { - } \quad \text { Project manager on a large-scale green roof project in London; and } \\
\text { - Experience in green roofs and design, legislation and compliance. }\end{array}$ \\
\hline Interviewee G & Male & $\begin{array}{l}\text { - } \quad \text { Practicing consultant; } \\
\text { - } \quad \text { PhD in sustainability studies; and } \\
\text { - } \quad \text { Research background in green infrastructure and its benefits. }\end{array}$ \\
\hline Interviewee $\mathbf{H}$ & Male & $\begin{array}{l}\text { - Highly regarded Australian green roof researcher; and } \\
\text { - Authored a number of published green roof journal articles and } \\
\text { other scholarly articles for an Australian context. }\end{array}$ \\
\hline Interviewee I & Female & $\begin{array}{l}\text { - } \quad \text { Previous board member of Green Roofs Australasia; } \\
\text { - Authored a number of published green roof journal articles and } \\
\text { other scholarly articles for an Australian context; }\end{array}$ \\
\hline
\end{tabular}

\section{References}

1. Carter, T.; Andrew, K. Life-cycle cost-benefit analysis of extensive vegetated roof systems. J. Environ. Manag. 2008, 87, 350-363. [CrossRef] [PubMed] 
2. Siew, R.Y.J. A review of sustainability reporting tools (SRTs) for communities. Int. J. Sustain. Constr. Eng. Technol. 2014, 5, 39-52.

3. Halliday, S. Sustainable Construction; Taylor and Francis: Southport, UK, 2008.

4. Bianchini, F.; Kasun, H. Probabilistic social cost-benefit analysis for green roofs: A lifecycle approach. Build. Environ. 2012, 58, 152-162. [CrossRef]

5. Castleton, H.F.; Stovin, V.; Beck, S.B.M.; Davison, J.B. Green roofs; building energy savings and the potential for retrofit. Energy Build. 2010, 42, 1582-1591. [CrossRef]

6. Farrell, C.; Mitchell, R.E.; Szota, C.; Rayner, J.P.; Williams, N.S.G. Green roofs for hot and dry climates: interacting effects of plant water use, succulence and substrate. Ecol. Eng. 2012, 49, 270-276. [CrossRef]

7. Kosareo, L.; Ries, R. Comparative environmental life cycle assessment of green roofs. Build. Environ. 2007, 42, 2606-2613. [CrossRef]

8. Berardi, U.; GhaffarianHoseini, A. State-of-the-art analysis of the environmental benefits of green roofs. Appl. Energy 2014, 115, 411-428. [CrossRef]

9. Butler, C.; Timothy, C. Ecological impacts of replacing traditional roofs with green roofs in two urban areas. Cities Environ. 2008, 1, 1-17.

10. Rayner, J.; Raynor, K.; Williams, N. Green roofs for a wide brown land: Opportunities and barriers for rooftop greening in Australia. Urban For. Urban Green. 2010, 9, 241-251.

11. Ely, M.; Sheryn, P. Life Support for Human Habitats: The Compelling Evidence for Incorporating Nature into Urban Environments. 2014. Available online: file:// C:/Users/263830g/Downloads/Green_Infrastructure_ Evidence_Base_2014.pdf (accessed on 25 November 2015).

12. Wilkinson, S.J.; Reed, R. Green roof retrofit potential in the central business district. Prop. Manag. 2009, 27, 284-301. [CrossRef]

13. Kucukvar, M.; Omer, T. Towards a triple bottom-line sustainability assessment of the U.S. construction industry. Int. J. Life Cycle Assess. 2013, 18, 958-972. [CrossRef]

14. Carter, T.; Laurie, F. Establishing green roof infrastructure through environmental policy instruments. Environ. Manag. 2008, 42, 151-164. [CrossRef] [PubMed]

15. Kibert, C.J. Sustainable Construction: Green Building Design and Delivery; John Wiley and Sons: Hoboken, NJ, USA, 2012.

16. Brundtland, G.H. Report of the World Commission on Environment and Development: Our Common Future. 1987. Available online: http://www.un-documents.net/our-common-future.pdf (accessed on 20 November 2015).

17. Fabricio, B.; Hewage, K. How "Green" are the green roofs? Lifecycle analysis of green roof materials. Build. Environ. 2012, 48, 57-65.

18. Feitosa, R.; Sara, W. Retrofitting housing with lightweight green roof technology in Sydney, Australia, and Rio de Janeiro, Brazil. J. Sustain. 2015, 7, 1081-1098.

19. Beecham, S.; Brien, C.J.; Razzaghmanesh, M. Developing resilient green roofs in a dry climate. Sci. Total Environ. 2014, 490, 579-589.

20. Dillion, M. Sky High but Down to Earth. Available online: http://www.airah.org.au/imis15_prod/Content_ Files/EcoLibrium/2008/November2008/2008-11-F04.pdf (accessed on 20 November 2015).

21. Aneli, S.; Gagliano, A.; Detommaso, M.; Nocera, F. The retrofit of existing buildings through the exploitation of the green roofs-A simulation study. Energy Procedia 2014, 62, 52-61.

22. Elley, T.B.; Max, G.; David, J.S. Exploring the building energy impacts of green roof design decisions-A modeling study of buildings in four distinct climates. J. Build. Phys. 2011, 35, 372-391.

23. Rahman, S.R.A.; Ahmad, H.; Mohammad, S.; Muhamad, S.L.R. Perception of green roof as a tool for urban regeneration in a commercial environment: The secret garden, Malaysia. Procedia Soc. Behav. Sci. 2013, 170, 128-136. [CrossRef]

24. Claus, K.; Sandra, R. Public versus private incentives to invest in green roofs: A cost benefit analysis for Flanders. Urban For. Urban Green. 2012, 11, 417-425. [CrossRef]

25. Gatersleben, B.; White, E. Greenery on residential buildings: Does it affect preferences and perceptions of beauty? J. Environ. Psychol. 2010, 31, 89-98.

26. Smith, C.; Boyer, M. Who wants to live with a living roof? Green Places 2007, 39, $24-27$.

27. Hien, W.N.; Yuen, B. Resident perceptions and expectations of rooftop gardens in Singapore. Landsc. Urban Plan. 2004, 73, 263-276. 
28. Koole, S.; Van Den Berg, A.; Wulp, N. Environmental preference and restoration: (How) are they related? J. Environ. Psychol. 2003, 23, 135-146.

29. Ulrich, R.S. Aesthetic and affective response to natural environment. Hum. Behav. Environ. 1983, 6, 88-125.

30. Hietanen, J.; Korpela, K.; Klemettila, T. Evidence for rapid affective evaluation of environmental scenes. Environ. Behav. 2002, 34, 634-650.

31. Farrell, C.; Kate, L.; Kathryn, W.; Leisa, S.; Nicholas, W. Living roof preference is influenced by plant characteristics and diversity. Landsc. Urban Plan. 2013, 122, 152-159.

32. Bruce, T.; Jian, Z.; Raufdeen, R.; Stephen, P. Factors influencing the retrofitting of existing office buildings using Adelaide, South Australia as a case study. Struct. Surv. 2015, 33, 150-166. [CrossRef]

33. Forbes, D.J. An Analysis of Municipal Tools for Promoting Green Roof Technology into Dense Urban Development. Masters' Thesis, Tufts University, Boston, MA, USA, Auguest 2010.

34. Weiler, S.K.; Katrin, S.B. Green Roof Systems: A Guide to the Planning, Design and Construction of Landscapes over Structure; John Wiley \& Sons: Hoboken, NJ, USA, 2009.

35. Perini, K.; Paolo, R. Cost-benefit analysis for green façades and living wall systems. Build. Environ. 2013, 70, 110-121. [CrossRef]

36. Ong, C.L.; Angelia, S.; Taya, S.F.; Wonga, N.H.; Wonga, R. Life cycle cost analysis of rooftop gardens in Singapore. Build. Environ. 2003, 38, 499-509.

37. Adriaens, P.; Corrie, C.; Brian, T. Green roof valuation: A probabilistic economic analysis of environmental benefits. Environ. Sci. Technol. 2008, 42, 2155-2161.

38. Finkbeiner, M.; Peri, G.; Rizzo, G.; Traverso, M. The cost of green roofs disposal in a life cycle perspective: Covering the gap. Energy 2012, 48, 406-414.

39. Andresen, J.; Bradley, R.; Clayton, L.R.; Lan, X.; Van Woert, N.D. Watering regime and green roof substrate design affect sedum plant growth. HortScience 2005, 40, 659-664.

40. Lundholm, J.; Scott, M. Performance evaluation of native plants suited to extensive green roof conditions in a maritime climate. Ecol. Eng. 2011, 37, 407-417.

41. McIntyre, L.; Snodgrass, E. The Green Roof Manual: A Professional Guide to Design, Installation, and Maintenance; Timber Press Incorporated: Portland, OR, USA, 2010.

42. Bradbury, D.; Hughes, R.; Jones, N.; Rayner, J.; Williams, N. The performance of native and exotic species for extensive green roofs. In Proceedings of the International Conference on Landscape and Urban Horticulture, Bologna, Italy, 9-13 June 2009.

43. Beecham, S.; Kazemi, F.; Razzaghmanesh, M. The growth and survival of plants in urban green roofs in a dry climate. Sci. Total Environ. 2014, 476, 228-297.

44. Nina, J.; Metternich, G. How to grow a green roof industry. In Proceedings of the 11th Annual Green Roof and Wall Conference, San Francisco, CA, USA, 23-26 October 2013.

45. Elliott, T. Green roofs growing in popularity. Sydney Morning Herald, 9 September 2008.

46. Bearman, C.; Michalski, D. Factors affecting the decision making of pilot who fly in outback Australia. Saf. Sci. 2014, 68, 288-293.

47. Bryman, A. Quantity and Quality in Social Research; Routledge: New York, NY, USA, 1988.

48. Heller, A.; Lammond, J.; Manion, J.; Proverbs, D.; Sharman, L.; Wilkinson, S. Technical considerations in green roof retrofit for stormwater attenuation in the Central Business District. Struct. Surv. 2014, 33, 36-51.

49. International Monetary Fund. Classifications of Countries Based on Their Level of Development: How It Is Done and How It Could Be Done. 2011. Available online: https://www.imf.org/external/pubs/ft/wp/ 2011/wp1131.pdf (accessed on 10 October 2015).

50. Australian Building Codes Board. National Construction Code Series-Volume One. 2016. Available online: http://www.abcb.gov.au/Resources/Publications/NCC/NCC-2016-Volume-One (accessed on 2 May 2016).

51. Government News. Available online: http://www.governmentnews.com.au/2015/10/new-cities-andbuilt-environment-taskforce/ (accessed on 18 May 2016).

52. Ministry of Environment and Water Resources. Available online: http://www.mewr.gov.sg/grab-ourresearch/singapore-green-plan-2012 (accessed on 16 May 2016).

53. Ministry of Environment and Water Resources. Available online: http://www.mewr.gov.sg/ssb/ (accessed on 16 May 2016).

54. Department of the Environment. Available online: https://www.environment.gov.au/cleaner-environment (accessed on 16 May 2016). 
55. Sibley, M.; Sibley, M. Hybrid green technologies for retrofitting heritage buildings in North African medinas: Combining vernacular and high-tech solutions for an innovative solar powered lighting system for hammam buildings. Energy Procedia 2013, 42, 718-725. [CrossRef]

56. International Standards Organisation. ISO 31000: 2009 Risk Management-Principles and Guidelines Sydney: Standards Australia \& Standards New Zealand. 2009. Available online: http://www.iso.org/iso/ catalogue_detail?csnumber $=43170$ (accessed on 18 May 2016).

57. UNESCO. The Persian Garden. Available online: http://whc.unesco.org/en/list/1372 (accessed on 25 May 2016).

58. Kok, K.H.; Mohd, S.L.; Chow, M.F.; Zainal Abidin, M.R.; Basri, H.; Hayder, G. Evaluation of green roof performances for urban stormwater quantity and quality controls. Int. J. River Basin Manag. 2016, 14, 1-7. [CrossRef]

59. Speak, A.F.; Rothwell, J.J.; Lindley, S.J.; Smith, C.L. Metal and nutrient dynamics on an aged intensive green roof. Environ. Pollut. 2014, 184, 33-43. [CrossRef] [PubMed]

60. Pisello, A.L.; Pignatta, G.; Castaldo, V.L.; Cotana, F. Experimental analysis of natural gravel covering as cool roofing and cool pavement. Sustainability 2014, 6, 4706-4722. [CrossRef]

61. Pisello, A.L.; Piselli, C.; Cotana, F. Thermal-physics and energy performance of an innovative green roof system: The cool-green roof. Solar Energy 2015, 116, 337-356. [CrossRef]

62. Li, X.X.; Norford, L.K. Evaluation of cool roof and vegetations in mitigating urban heat island in a tropical city, Singapore. Urban Clim. 2016, 16, 59-74. [CrossRef]

63. Fexas, M. Green roofs and vegetated systems for a sustainable future. Aust. Gard. Hist. 2010, $21,8-12$.

64. Beecham, S.; Kazemi, F.; Razzaghmanesh, M. The role of green roofs in water sensitive urban design in South Australia. In Proceedings of the 7th International Conference on Water Sensitive Urban Design, Melbourne, Australia, 21-23 February 2012.

65. Gliedt, T.; Hoicka, C.E. Energy upgrades as financial or strategic investment? Energy Star property owners and managers improving building energy performance. Appl. Energy 2015, 147, 430-443. [CrossRef]

66. City of Sydney. Available online: http://www.cityofsydney.nsw.gov.au/vision/towards-2030/ sustainability/greening-the-city/green-roofs-and-walls\#page-element-dload (accessed on 27 May 2016).

67. Growing Green Guide. Available online: http://www.growinggreenguide.org/ (accessed on 27 May 2016).

68. VOYANT See through Your Text. Available online: http://voyant-tools.org/ (accessed on 2 June 2016).

69. Porter, F.C. Testing Consistency of Two Histograms; Cornell University Libarary: Ithaca, NY, USA, 2008; Available online: http://www.hep.caltech.edu/ fcp/statistics/hypothesisTest/PoissonConsistency/ PoissonConsistency.pdf (accessed on 5 June 2016). 